\title{
REVIEW
}

\section{Potential role of IFNa in adult lupus}

\author{
Lars Rönnblom*
}

\begin{abstract}
Patients with lupus have a continuous production of IFNa and display an increased expression of IFNaregulated genes. The reason for the ongoing IFNa synthesis in these patients seems to be an activation of plasmacytoid dendritic cells (pDCs) by immune complexes (ICs), consisting of autoantibodies in combination with DNA-containing or RNA-containing autoantigens. The mechanisms behind the activation of pDCs by such ICs have to some extent been elucidated during the last years. Thus, interferogenic ICs are internalized via the FcyRlla expressed on pDCs, reach the endosomes and stimulate Toll-like receptor (TLR) 7 or 9, which subsequently leads to IFNa gene transcription. Variants of genes involved in both the IFNa synthesis and response have been linked to an increased risk to develop lupus. Among these genes are interferon regulatory factor 5 (IRF5), which is involved in TLR signaling, and the signal transducer and activator of transcription 4 (STAT4) that interacts with the type I interferon receptor. Produced IFNa may at least partially be responsible for several of the observed alterations in the immune system of lupus patients and contribute to the autoimmune disease process, which will be discussed in the present review. How produced IFNa can contribute to some clinical manifestations will briefly be described, as well as the possible consequences of this knowledge in clinical practice for disease monitoring and therapy.
\end{abstract}

\section{Introduction}

Systemic lupus erythematosus, or lupus, is one of the most intriguing diseases due to its diverse clinical picture, variable course and in the single patient also its unpredictable outcome. The etiopathogenesis of lupus has been studied intensively for many years and the disease has long been regarded as the prototype autoimmune disease. The

*Correspondence: Lars.Ronnblom@medsci.uu.se

Department of Medical Sciences, Section of Rheumatology, Uppsala University, Uppsala University Hospital, Entrance 40, SE-751 85 Uppsala, Sweden reason for this is that a large number of different autoantibodies are produced in lupus patients and that most, if not all, cells in the immune system seem to be involved in the disease process.

The most prominent feature in lupus is an immune response to nucleic acid and associated proteins, which results in autoantibody production, immune complex (IC) formation and organ inflammation. In addition, most lupus patients display several signs of an increased IFN $\mathrm{N}$ production, which during the past years has attracted much interest regarding the possible role of this cytokine in the disease process. This interest has been further inspired by the observation that IFN $\alpha$ administration to individuals without any autoimmune condition can trigger the production of antinuclear autoantibodies, and occasionally also a lupus syndrome.

In the present review, the possible reason(s) behind the ongoing IFN $\alpha$ production in lupus will be reviewed, as well as the role of IFNa in the etiopathogenesis and the clinical manifestations of the disease. The potential application in clinical practice of our present knowledge of the type I interferon system in lupus will also be discussed.

\section{IFNa in lupus patients}

The first described cytokine abnormality in lupus patients was an increased serum level of interferon [1], which subsequently was characterized as IFN $\alpha$ [2]. Early studies also demonstrated that lupus patients have increased levels of IFN $\alpha$-induced proteins, such as $2^{\prime}, 5^{\prime}$-adenylate synthetase [3] and MxA [4]. The latter report showed that $>90 \%$ of lupus patients displayed increased expression of MxA, even if measurable serum IFNo levels could not be detected. Further studies showed that serum IFN $\alpha$ levels correlated to disease activity, but also to signs of immune activation and several clinical disease manifestations [5].

Functional analysis of type I interferon activity in serum from lupus patients has revealed that there is an association between serum interferon activity and immunological phenotype [6]. When genome-wide gene expression profiling became available, several research groups observed that a large proportion of lupus patients have an increased expression of type I interferon-regulated genes (an interferon signature) in peripheral blood 
mononuclear cells [7-10], but also in affected organs such as the kidneys [11]. The interferon signature was observed in almost all pediatric lupus patients with active disease of recent onset [7]; in adults with more longlasting and less active disease, in comparison, approximately one-half of the patients displayed the interferon signature $[8,9]$.

\section{Induction of IFNa production in lupus}

The natural interferon-producing cell, also termed the plasmacytoid dendritic cell (pDC), has the unique capacity to secrete up to $10^{9} \mathrm{IFN \alpha}$ molecules per cell in response to viral infections [12]. These cells appear to be the major type I interferon-producing cell for many different interferon inducers, including both viruses and bacteria. The prominent signs of an ongoing IFN $\alpha$ production in lupus therefore raise questions of the natural interferon-producing cell/pDC function and the potential IFN $\alpha$ inducers in these patients.

\section{Natural interferon-producing cells/plasmacytoid dendritic cells}

Several studies have shown that the frequency of circulating pDCs is markedly reduced in lupus patients [13-15], although residual single cells upon stimulation have a normal IFN $\alpha$-producing capacity. The reason for the decreased number of circulating pDCs seems to be a migration of these cells to tissues, because an increased number of pDCs can readily be detected in the skin $[16,17]$, in lymph nodes [18] and in renal tissue [19] from lupus patients. pDCs are furthermore activated in vivo and synthesize IFN $\alpha$, which indicates that these cells are responsible for the continuous IFN $\alpha$ production in lupus.

The pDCs can be activated to IFN $\alpha$ production via triggering of Toll-like receptor (TLR) 7 or TLR9, which sense single-stranded RNA and CpG-containing DNA, respectively (reviewed in [20]). These receptors are localized in the endosome to prevent activation by self RNA or DNA. Ligation of the TLRs leads to interaction with the myeloid differentiation factor 88 adaptor protein and subsequent phosphorylation of several transcription factors, among which interferon regulatory factor (IRF) 5 and IRF7 are most important. In addition, the TLR9mediated induction of type I interferon production requires an intact mammalian target of rapamycin pathway [21].

\section{Inducers of IFNa in lupus}

In the search for an endogenous IFN $\alpha$ inducer in lupus, we noted that sera from such patients contain ICs consisting of autoantibodies and DNA with the capacity to specifically activate pDCs [22,23]. Further studies revealed that such interferogenic ICs are internalized via the FcyRIIa expressed on pDCs [24], reach the endosome and stimulate the relevant TLR with subsequent activation of transcription factors and IFN $\alpha$ production [25]. This mechanism for induction of type I interferon production has been demonstrated in vitro for both DNA-containing and RNA-containing ICs. The nucleicacid-containing autoantigens in the interferogenic ICs can be generated from apoptotic or necrotic cells [26], which is relevant given the increased apoptosis and reduced clearance of apoptotic cells in lupus [27]. Several molecules are involved in the IFN $\alpha$ response to these ICs. The high-mobility group box 1 protein/receptor for advanced glycation end-products interaction is necessary for the TLR9-induced IFN $\alpha$ production by DNA-containing ICs [28], whereas $\mathrm{C} 1 \mathrm{q}$ decreases the IFN $\alpha$ production by interferogenic ICs [29].

There exist several different ICs with the capacity to activate $\mathrm{pDCs}$, but RNA-containing ICs that trigger TLR7 seem to be especially potent as IFNa inducers $[30,31]$. There is also a correlation in lupus patients between serum IFN $\alpha$ activity and the presence of autoantibodies to RNA binding proteins [6]. Such autoantibodies appear very early in the development of the disease, usually several years before the appearance of clinical overt lupus disease [32]. Since some of these autoantibodies show cross-reactivity with viral epitopes, the initial trigger for the production of antibodies with IFN $\alpha$ inducting capacity could well be a viral infection [33]. This scenario would connect viral infections with the generation of interferogenic ICs, with the capacity to create a self-perpetuating vicious circle driven by IFN $\alpha$ [34] (see Figure 1).

\section{Genetic susceptibility}

One obvious question is whether certain individuals have an enhanced IFN $\alpha$ production or sensitivity, which could increase the risk to develop lupus if nucleic-acidcontaining ICs appear. The observation that a high serum IFN $\alpha$ activity seems to be a heritable risk factor for lupus [35] indicates that the genetic control of the type I interferon system is important for the risk to develop this disease (for a comprehensive review, see article S3 in this supplement).

The transcription factor IRF5, which is constitutively expressed in pDCs [36], was the first identified gene directly involved in IFN $\alpha$ production that was associated with increased risk for lupus [37]. The allele variants with the highest probability of being causal were identified recently, and were shown to affect the IRF5 expression, which is increased in peripheral blood mononuclear cells from lupus patients [38]. An IRF5 risk haplotype is associated with a high serum IFN $\alpha$ activity in patients, and especially in those with autoantibodies to RNA binding proteins or double-stranded DNA [39], linking lupus genetic susceptibility to the presence of interferogenic ICs. 


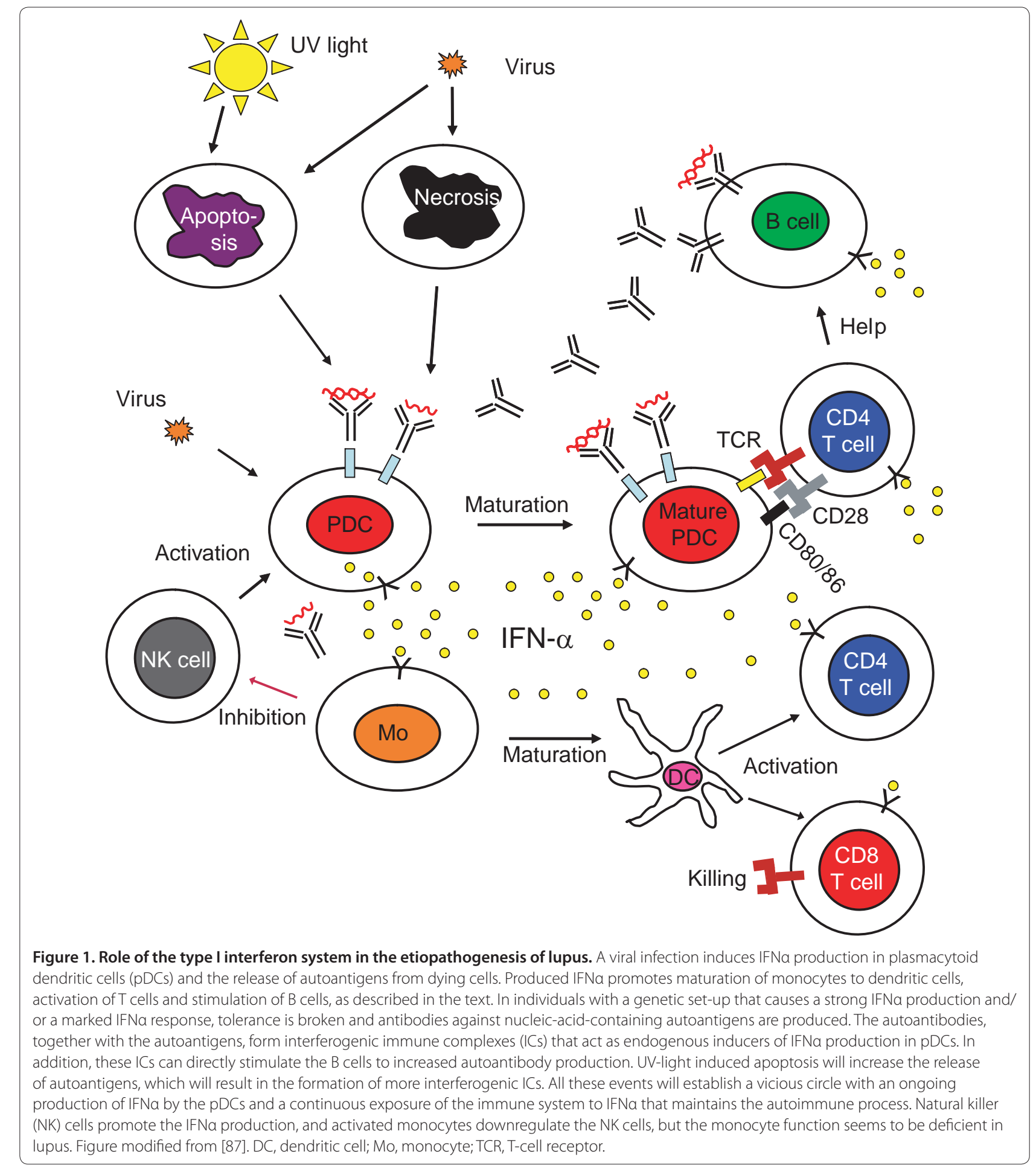

The IL-1 receptor-associated kinase, which is involved in TLR signaling and IFN $\alpha$ production, is also associated with lupus [40], which further strengthens the view that the genetic control of the IFN $\alpha$ production is important for the risk to develop lupus. The importance of the TLR pathways in this disease is further underscored by the observations that gene variants of the TNF $\alpha$-induced protein 3 is associated with increased risk for lupus [41,42].

Among genes involved in the response to IFN $\alpha$, the signal transducer and activator of transcription 4 (STAT4) that interacts with the cytoplasmic part of the type I interferon receptor (IFNAR) [43] is strongly associated 
with lupus [44]. In lupus patients there is an association between the STAT4 genotype, increased sensitivity to IFN $\alpha$ [45] and a more severe phenotype, which includes nephritis and the presence of anti-double-stranded DNA autoantibodies [46,47]. Polymorphisms in the Janus kinase tyrosine kinase 2, which binds to the IFNAR and is required for signaling through this receptor, is also associated with lupus $[37,48]$.

These data provide further evidence for a link between the IFN $\alpha$ response and the disease process in lupus. Additional susceptibility genes for lupus can be involved in the activation of the type I interferon system by other mechanisms - for instance, via increased production of autoantibodies and subsequent generation of more interferogenic ICs [49].

\section{Consequences of the ongoing IF Na production in lupus}

What are the consequences of the ongoing IFN $\alpha$ synthesis in lupus patients? Produced IFN $\alpha$ will affect most cells in the immune system and can therefore stimulate the central autoimmune process, but IFN $\alpha$ will also contribute to the expression of some clinical signs and symptoms.

\section{IFNa and autoimmunity}

The possible role of IFNa as an inducer of lupus was originally suggested by the observation that the administration of IFN $\alpha$ to a patient with a malignant disease induced a lupus syndrome indistinguishable from naturally occurring lupus [50]. During the years, many reports have described the induction of several different autoimmune diseases during prolonged treatment of patients with IFN $\alpha$ [51]. The presence of autoantibodies in patient sera before the onset of IFN $\alpha$ therapy considerably increases the risk for development of clinical overt autoimmune disease during IFN $\alpha$ administration [52]. These observations demonstrate that IFN $\alpha$ has the capacity to both break the tolerance and enhance a smoldering autoimmune process.

The mechanisms behind the pro-autoimmune effects of IFN $\alpha$ are not clear, but there exist several possibilities. First, IFN $\alpha$ can induce increased expression of autoantigens, such as Ro52 [7,8], but can also promote the release of autoantigens by induction of apoptosis [53]. Secondly, IFN $\alpha$ has multiple effects in both the innate and adaptive immune systems, which best can be described as a general activation of the immune cells. IFN $\alpha$ thus induces dendritic cell maturation and activation, with increased expression of MHC class I and II molecules, chemokines and chemokine receptors, costimulatory molecules such as CD80, CD86, the B-lymphocyte stimulator and a proliferation-inducing ligand [54]. Importantly, IFNa can also induce the expression of TLR7 [55], which may enhance the responsiveness to interferogenic ICs. The development of helper $\mathrm{T}$ cells along the T-helper type 1 pathway is promoted, and cytotoxic $\mathrm{T}$ cells are stimulated by type I interferons, due to an increase in dendritic cell crosspresentation, inhibition of T-cell apoptosis as well as stimulation of IL- 2 secretion by central memory T cells [56]. Type I interferons cause B-cell activation, differentiation, antibody production and immunoglobulin isotype class switching [57,58], but can also decrease the selectivity of B cells for CpG-rich DNA and allow stimulation by even non-CpG DNA [59] - thereby promoting an autoimmune response. Consequently, several IFN $\alpha$-mediated effects can contribute to the autoimmune process in the pathogenesis of lupus. Figure 1 shows a schematic view of the possible role of IFN $\alpha$ in the disease process.

IFN $\alpha$ production is affected by several cytokines and cells in the immune system. TNF $\alpha$ and IL-10 can downregulate the IC-mediated IFN $\alpha$ production [60], and TNF $\alpha$ also inhibits the generation of pDCs [61]. The IFNo response is furthermore regulated by several cells in the immune system, such as natural killer cells and monocytes. Natural killer cells promote the IFNa production whereas the monocytes downregulate the type I IFN $\alpha$ response, and this control mechanism may be deficient in lupus patients [62]. The complex interaction between the different cytokines and the immune system in lupus patients may be further clarified by a network-based analysis of abnormally regulated genes in these patients [63].

\section{IFNa and disease manifestation}

Several observations suggest that IFN $\alpha$ may have an important role in some of the clinical manifestations in lupus patients. There is an association between increased serum levels of IFN $\alpha$ and fever, skin rash and leucopenia [5], which perhaps is not surprising considering these symptoms are commonly seen during viral infections. Among the more specific lupus manifestations, an early study observed that patients with lupus psychosis have detectable levels of IFN $\alpha$ in the cerebrospinal fluid [64], which is intriguing given the observed neuropsychiatric adverse effects during IFNa treatment [65]. Recently, autoantibodies with the ability to form very potent interferogenic ICs together with RNA-containing autoantigens were demonstrated in the cerebrospinal fluid of lupus patients with neuropsychiatric manifestations [66]. These ICs also induced other chemokines and proinflammatory cytokines of possible relevance for the central nervous system manifestations frequently seen in lupus, which indicates that the interferogenic ICs may be directly involved in central nervous system lupus.

Results from an experimental model suggest that IFN $\alpha$ can drive the nephritis and end organ damage in lupus 
[67], and it has been shown that pDCs accumulate in active human lupus nephritis [19]. These observations are in line with the findings that major organ involvement in lupus patients, including nephritis, is connected to a more pronounced IFN $\alpha$ signature [8] and that IFNoregulated genes are overexpressed in the glomeruli from lupus nephritis [11]. The role of IFN $\alpha$ in the premature atherosclerosis typically seen in lupus patients is unclear, but IFN $\alpha$ may contribute to the atherosclerotic process by impairing endothelial cell differentiation [68]. Furthermore, pDCs are present in atherosclerotic plaques from carotid lesions where, via produced IFN $\alpha$, they can act as inflammatory amplifiers and destabilize the plaque [69].

\section{IFNa in clinical practice}

We are at the beginning of an era were the basic knowledge of the type I interferon system in lupus is translated into clinical useful tools for monitoring and treating patients.

\section{IFNa as a biomarker}

There is a correlation between the serum levels of IFN $\alpha$ and disease activity in lupus patients, as mentioned above. Owing to difficulties in measuring IFN $\alpha$ in serum, however, most investigators study the interferon signature as a potential biomarker. A more pronounced interferon signature is seen in patients with active disease and major disease manifestations, such as nephritis, cerebritis, hematological manifestations and increased damage index [7,8,70-72]. Administration of high doses of corticosteroids to lupus patients with active disease, which induces clinical remission, will normalize the interferon signature [7]. These observations have demonstrated a connection between the IFN $\alpha$ signature and the clinical status of the patients. Whether determination of the interferon-induced gene expression can be used to closely monitor the disease activity in single patients during longitudinal follow-up is uncertain, however, because the interferon signature seems to remain stable in the patients despite changes in disease activity [72,73]. On the other hand, two preliminary reports have suggested that the interferon-gene profile of peripheral blood cells could predict future disease activity $[74,75]$.

At the moment, the clinical value of monitoring the IFN $\alpha$ signature during long-term follow-up remains to be established. Two other approaches to follow disease activity are either to look at expression of type I interferon-regulated molecules on cells involved in the disease process, such as Siglec-1 on monocytes [76], or to measure the level of interferon-regulated chemokines [77]. Interestingly, the interferon-regulated chemokines may also be connected to organ damage [78].

There is also a possibility that genes within the type I interferon signaling pathway can be used as biomarkers for organ involvement and severity. There is thus an association between the STAT4 genotype and risk for a more severe disease phenotype that includes nephritis $[46,47]$ and stroke [79]. The latter observation is interesting, because the association between a STAT4 risk variant and stroke was of the same magnitude as the association between stroke and hypertension, indicating that autoimmune processes may be very important for many disease manifestations in lupus, even those that traditionally not are regarded as autoimmune. Furthermore, a combination of risk alleles within the type I interferon signaling pathway dramatically increases the risk for lupus [47], which illustrates how genetic mapping in the future perhaps could aid in the prediction of risk for disease.

\section{IFNa as a therapeutic target}

Because many observations indicate a crucial role for the type I interferon system and IFNa in the etiology and pathogenesis of human lupus, several companies are developing therapies aiming to inhibit the type I interferon production or effects in the disease. This development has been stimulated by the fact that type I IFNARknockout murine lupus models have a reduced disease activity [80,81].

Results from the first phase I clinical trial using a single injection of anti-IFN $\alpha$ monoclonal antibodies in lupus patients were recently reported $[82,83]$. The anti-IFN $\alpha$ treatment caused a dose-dependent inhibition of the type I interferon inducible genes in both peripheral blood and skin biopsies, as well a reduction in clinical disease activity. In addition, granulocyte-macrophage colonystimulating factor, TNF $\alpha$, IL-10 and IL-1 $\beta$ inducible gene signatures, as well as B-cell activating factor mRNA expression, were neutralized in some patients [83] demonstrating the interaction between the type I interferon system and other proinflammatory pathways. The observation that a single injection of an anti-IFN $\alpha$ antibody could give a sustained neutralization of the interferon signature is of particular interest, and supports the view that the ongoing production of interferon in lupus is at least partly a result of a self-perpetuating vicious circle [34] (Figure 1). No increase in serious viral infections has so far been reported among anti-IFN $\alpha$ treated patients, which could be due to the fact that besides IFN $\alpha$ there exist several other type I interferons with strong antiviral activity [84]. Whether these latter type I interferons are sufficient potent to protect antiIFNo-treated lupus patients from serious complications during, for instance, a flu pandemic remains to be established, and can only be addressed in larger clinical trials.

There exist other possible therapeutic targets within the type I interferon system, such as the IFNAR, the BDCA-2 antigen on pDC [14,85] or oligodeoxyribo- 
nucleotide or oligoribonucleotide TLR antagonists [86]. None of these agents have so far been tested in human lupus patients.

In conclusion, the type I interferon system is activated in lupus patients with ongoing IFN $\alpha$ production, which is of major importance for the disease process. The genetic and immunological background to this overproduction of IFN $\alpha$ is to some extent clarified, but several questions still remain to be answered. Despite this, several studies aiming to target the increased IFN $\alpha$ levels or its effects in lupus patients are planned, or are in the early clinical phase. These treatment regimes will hopefully bring relief to our patients without interfering with the normal function of the type I interferon system.

\section{Abbreviations}

IC = immune complex; IFN = interferon; IFNAR = type I interferon receptor; $\mathrm{IL}$ = interleukin; IRF = interferon regulatory factor; $\mathrm{pDC}=$ plasmacytoid dendritic cell; STAT = signal transducer and activator of transcription; TLR = toll-like receptor; TNF = tumor necrosis factor

\section{Competing interests}

LR has served on the advisory board for Active Biotech Research Inc., Medlmmune Inc. and Novo Nordisk A/S.

\section{Acknowledgements}

The present work was supported by The Alliance for Lupus Research, the Swedish Research Council, the Dana Foundation, the Swedish Rheumatism Association, the Gustafsson Foundation, the King Gustaf V 80th Birthday Foundation and COMBINE.

This article is part of Arthritis Research \& Therapy Volume 12 Supplement 1: The role of IFN alpha in autoimmune disease. The full contents of the supplement are available online at http://arthritis-research.com/supplements/12/S1 . Publication of the supplement has been supported with funding from Medlmmune, LLC

Published: 14 April 2010

\section{References}

1. Hooks JJ, Moutsopoulos HM, Geis SA, Stahl NI, Decker JL, Notkins AL: Immune interferon in the circulation of patients with autoimmune disease. N Engl J Med 1979, 301:5-8.

2. Ytterberg SR, Schnitzer TJ: Serum interferon levels in patients with systemic lupus erythematosus. Arthritis Rheum 1982, 25:401-406.

3. Preble OT, Rothko K, Klippel JH, Friedman RM, Johnston MI: Interferoninduced $2^{\prime}-5^{\prime}$ adenylate synthetase in vivo and interferon production in vitro by lymphocytes from systemic lupus erythematosus patients with and without circulating interferon. J Exp Med 1983, 157:2140-2146.

4. von Wussow P, Jakschies D, Hochkeppel H, Horisberger M, Hartung K, Deicher $H$ : MX homologous protein in mononuclear cells from patients with systemic lupus erythematosus. Arthritis Rheum 1989, 32:914-918.

5. Bengtsson A, Sturfelt G, Truedsson L, Blomberg J, Alm G, Vallin H, Rönnblom $L$ : Activation of type I interferon system in systemic lupus erythematosus correlates with disease activity but not antiretroviral antibodies. Lupus 2000, 9:664-671.

6. Hua J, Kirou K, Lee C, Crow MK: Functional assay of type I interferon in systemic lupus erythematosus plasma and association with anti-RNA binding protein autoantibodies. Arthritis Rheum 2006, 54:1906-1916.

7. Bennett L, Palucka AK, Arce E, Cantrell V, Borvak J, Banchereau J, Pascual V: Interferon and granulopoiesis signatures in systemic lupus erythematosus blood. J Exp Med 2003, 197:711-723

8. Baechler EC, Batliwalla FM, Karypis G, Gaffney PM, Ortmann WA, Espe KJ, Shark KB, Grande WJ, Hughes KM, Kapur V, Gregersen PK, Behrens TW Interferon-inducible gene expression signature in peripheral blood cells of patients with severe lupus. Proc Natl Acad Sci USA 2003, 100:2610-2615.
9. Crow MK, Wohlgemuth J: Microarray analysis of gene expression in lupus. Arthritis Res Ther 2003, 5:279-287.

10. Han GM, Chen SL, Shen N, Ye S, Bao CD, Gu YY: Analysis of gene expression profiles in human systemic lupus erythematosus using oligonucleotide microarray. Genes Immun 2003, 4:177-186.

11. Peterson KS, Huang JF, Zhu J, D’Agati V, Liu X, Miller N, Erlander MG, Jackson MR, Winchester RJ: Characterization of heterogeneity in the molecular pathogenesis of lupus nephritis from transcriptional profiles of lasercaptured glomeruli. J Clin Invest 2004, 113:1722-1733.

12. Fitzgerald-Bocarsly P, Dai J, Singh S: Plasmacytoid dendritic cells and type I IFN: 50 years of convergent history. Cytokine Growth Factor Rev 2008, 19:3-19.

13. Cederblad B, Blomberg S, Vallin H, Perers A, Alm GV, Rönnblom L: Patients with systemic lupus erythematosus have reduced numbers of circulating natural interferon-a-producing cells. J Autoimmun 1998, 11:465-470.

14. Blomberg S, Eloranta M-L, Magnusson M, Alm GV, Rönnblom L: Expression of the markers BDCA- 2 and -4 and production of interferon- $a$ by plasmacytoid dendritic cells in systemic lupus erythematosus. Arthritis Rheum 2003, 48:2524-2532.

15. Robak E, Sysa-Jedrzejowska A, Robak T, Smolewski P: Peripheral blood lymphocyte apoptosis and circulating dendritic cells in patients with systemic lupus erythematosus: correlation with immunological status and disease-related symptoms. Clin Rheumatol 2006, 25:225-233.

16. Blomberg S, Eloranta M-L, Cederblad B, Nordlind K, Alm GV, Rönnblom L: Presence of cutaneous interferon-a producing cells in patients with systemic lupus erythematosus. Lupus 2001, 10:484-490.

17. Farkas L, Beiske K, Lund-Johansen F, Brandtzaeg P, Jahnsen FL: Plasmacytoid dendritic cells (natural interferon- $\alpha / \beta$-producing cells) accumulate in cutaneous lupus erythematosus lesions. Am J Pathol 2001, 159:237-243.

18. Rönnblom L, Alm GV: The natural interferon-a producing cells in systemic lupus erythematosus. Hum Immuno/ 2002, 63:1181-1193.

19. Tucci M, Quatraro C, Lombardi L, Pellegrino C, Dammacco F, Silvestris F: Glomerular accumulation of plasmacytoid dendritic cells in active lupus nephritis: role of interleukin-18. Arthritis Rheum 2008, 58:251-262.

20. Gilliet M, Cao W, Liu YJ: Plasmacytoid dendritic cells: sensing nucleic acids in viral infection and autoimmune diseases. Nat Rev Immunol 2008, 8:594-606.

21. Cao W, Manicassamy S, Tang H, Kasturi SP, Pirani A, Murthy N, Pulendran B: Toll-like receptor-mediated induction of type I interferon in plasmacytoid dendritic cells requires the rapamycin-sensitive PI(3)K-mTOR-p70S6K pathway. Nat Immunol 2008, 9:1157-1164.

22. Vallin H, Blomberg S, Alm GV, Cederblad B, Rönnblom L: Patients with systemic lupus erythematosus (SLE) have a circulating inducer of interferon-alpha (IFN-a) production acting on leucocytes resembling immature dendritic cells. Clin Exp Immunol 1999, 115:196-202.

23. Vallin H, Perers A, Alm GV, Rönnblom L: Anti-double-stranded DNA antibodies and immunostimulatory plasmid DNA in combination mimic the endogenous IFN- $a$ inducer in systemic lupus erythematosus. $\mathrm{J}$ Immunol 1999, 163:6306-6313.

24. Båve U, Magnusson M, Eloranta M-L, Perers A, Alm GV, Rönnblom L: FcgRIla is expressed on natural IFN-a producing cells (plasmacytoid dendritic cells) and is required for the IFN-a production induced by apoptotic cells combined with lupus IgG. J Immuno/ 2003, 171:3296-3302.

25. Rönnblom L, Eloranta ML, Alm GV: The type I interferon system in systemic lupus erythematosus. Arthritis Rheum 2006, 54:408-420.

26. Lövgren T, Eloranta ML, Båve U, Alm GV, Rönnblom L: Induction of interferon-a production in plasmacytoid dendritic cells by immune complexes containing nucleic acid released by necrotic or late apoptotic cells and lupus IgG. Arthritis Rheum 2004, 50:1861-1872.

27. Munoz LE, van Bavel C, Franz S, Berden J, Herrmann M, van der Vlag J: Apoptosis in the pathogenesis of systemic lupus erythematosus. Lupus 2008, 17:371-375.

28. Tian J, Avalos AM, Mao SY, Chen B, Senthil K, Wu H, Parroche P, Drabic S, Golenbock D, Sirois C, Hua J, An LL, Audoly L, La Rosa G, Bierhaus A, Naworth P, Marshak-Rothstein A, Crow MK, Fitzgerald KA, Latz E, Kiener PA, Coyle AJ: Toll-like receptor 9-dependent activation by DNA-containing immune complexes is mediated by HMGB1 and RAGE. Nat Immuno/ 2007, 8:487-496.

29. Lood C, Gullstrand B, Truedsson L, Olin Al, Alm GV, Rönnblom L, Sturfelt G, Eloranta ML, Bengtsson AA: C1q inhibits immune complex-induced IFNa production in plasmacytoid dendritic cells. A novel link between $\mathrm{C} 1 \mathrm{q}$ deficiency and systemic lupus erythematosus pathogenesis. Arthritis Rheum 2009, 60:3081-3091. 
30. Vollmer J, Tluk S, Schmitz C, Hamm S, Jurk M, Forsbach A, Akira S, Kelly KM Reeves WH, Bauer S, Krieg AM: Immune stimulation mediated by autoantigen binding sites within small nuclear RNAs involves Toll-like receptors 7 and 8. J Exp Med 2005, 202:1575-1585.

31. Lövgren T, Eloranta ML, Kastner B, Wahren-Herlenius M, Alm GV, Rönnblom L: Induction of interferon-a by immune complexes or liposomes containing systemic lupus erythematosus autoantigen- and Sjögren's syndrome autoantigen-associated RNA. Arthritis Rheum 2006, 54:1917-1927.

32. Arbuckle MR, McClain MT, Rubertone MV, Scofield RH, Dennis GJ, James JA, Harley JB: Development of autoantibodies before the clinical onset of systemic lupus erythematosus. N Engl J Med 2003, 349:1526-1533.

33. McClain MT, Heinlen LD, Dennis GJ, Roebuck J, Harley JB, James JA: Early events in lupus humoral autoimmunity suggest initiation through molecular mimicry. Nat Med 2005, 11:85-89.

34. Rönnblom L, Alm GV: An etiopathogenic role for the type I IFN system in SLE. Trends Immunol 2001, 22:427-431.

35. Niewold TB, Hua J, Lehman TJ, Harley JB, Crow MK: High serum IFN-a activity is a heritable risk factor for systemic lupus erythematosus. Genes Immun 2007, 8:492-502.

36. Izaguirre A, Barnes BJ, Amrute S, Yeow WS, Megjugorac N, Dai J, Feng D, Chung E, Pitha PM, Fitzgerald-Bocarsly P: Comparative analysis of IRF and IFN-alpha expression in human plasmacytoid and monocyte-derived dendritic cells. J Leukoc Bio/ 2003, 74:1125-1138.

37. Sigurdsson S, Nordmark G, Göring HH, Lindroos K, Wiman AC, Sturfelt G, Jönsen A, Rantapää-Dahlqvist S, Möller B, Kere J, Koskenmies S, Widen E, Eloranta ML, Julkunen H, Kristjansdottir H, Steinsson K, Alm G, Rönnblom L, Syvänen AC: Polymorphisms in the tyrosine kinase 2 and interferon regulatory factor 5 genes are associated with systemic lupus erythematosus. Am J Hum Genet 2005, 76:528-537.

38. Sigurdsson S, Goring HH, Kristjansdottir G, Milani L, Nordmark G, Sandling J, Eloranta ML, Feng D, Sangster-Guity N, Gunnarsson I, Svenungsson E, Sturfelt G, Jonsen A, Truedsson L, Barnes BJ, Alm G, Rönnblom L, Syvanen AC: Comprehensive evaluation of the genetic variants of interferon regulatory factor 5 reveals a novel $5 \mathrm{bp}$ length polymorphism as strong risk factor for systemic lupus erythematosus. Hum Mol Genet 2008, 17:872-881.

39. Niewold TB, Kelly JA, Flesch MH, Espinoza LR, Harley JB, Crow MK: Association of the IRF5 risk haplotype with high serum interferon-a activity in systemic lupus erythematosus patients. Arthritis Rheum 2008, 58:2481-2487.

40. Jacob CO, Zhu J, Armstrong DL, Yan M, Han J, Zhou XJ, Thomas JA, Reiff A, Myones BL, Ojwang JO, Kaufman KM, Klein-Gitelman M, McCurdy D, WagnerWeiner L, Silverman E, Ziegler J, Kelly JA, Merrill JT, Harley JB, RamseyGoldman R, Vila LM, Bae SC, Vyse TJ, Gilkeson GS, Gaffney PM, Moser KL, Langefeld CD, Zidovetzki R, Mohan C: Identification of IRAK1 as a risk gene with critical role in the pathogenesis of systemic lupus erythematosus. Proc Natl Acad Sci U S A 2009, 106:6256-6261.

41. Musone SL, Taylor KE, Lu TT, Nititham J, Ferreira RC, Ortmann W, Shifrin N, Petri MA, Kamboh MI, Manzi S, Seldin MF, Gregersen PK, Behrens TW, Ma A, Kwok PY, Criswell LA: Multiple polymorphisms in the TNFAIP3 region are independently associated with systemic lupus erythematosus. Nat Genet 2008, 40:1062-1064

42. Graham RR, Cotsapas C, Davies L, Hackett R, Lessard CJ, Leon JM, Burtt NP, Guiducci C, Parkin M, Gates C, Plenge RM, Behrens TW, Wither JE, Rioux JD, Fortin PR, Graham DC, Wong AK, Vyse TJ, Daly MJ, Altshuler D, Moser KL, Gaffney PM: Genetic variants near TNFAIP3 on $6 \mathrm{q} 23$ are associated with systemic lupus erythematosus. Nat Genet 2008, 40:1059-1061.

43. Tyler DR, Persky ME, Matthews LA, Chan S, Farrar JD: Pre-assembly of STAT4 with the human IFN- $\alpha / \beta$ receptor -2 subunit is mediated by the STAT4 $\mathrm{N}$-domain. Mol Immunol 2007, 44:1864-1872.

44. Remmers EF, Plenge RM, Lee AT, Graham RR, Hom G, Behrens TW, de Bakker PI, Le JM, Lee HS, Batliwalla F, Li W, Masters SL, Booty MG, Carulli JP, Padyukov L, Alfredsson L, Klareskog L, Chen WV, Amos Cl, Criswell LA, Seldin MF, Kastner DL, Gregersen PK: STAT4 and the risk of rheumatoid arthritis and systemic lupus erythematosus. N Engl J Med 2007, 357:977-986.

45. Kariuki SN, Kirou KA, MacDermott EJ, Barillas-Arias L, Crow MK, Niewold TB. Cutting edge: autoimmune disease risk variant of STAT4 confers increased sensitivity to IFN-a in lupus patients in vivo. J Immuno/ 2009, 182:34-38.

46. Taylor KE, Remmers EF, Lee AT, Ortmann WA, Plenge RM, Tian C, Chung SA, Nititham J, Hom G, Kao AH, Demirci FY, Kamboh MI, Petri M, Manzi S, Kastner DL, Seldin MF, Gregersen PK, Behrens TW, Criswell LA: Specificity of the STAT4 genetic association for severe disease manifestations of systemic lupus erythematosus. PLoS Genet 2008, 4:e1000084.
47. Sigurdsson S, Nordmark G, Garnier S, Grundberg E, Kwan T, Nilsson O, Eloranta ML, Gunnarsson I, Svenungsson E, Sturfelt G, Bengtsson AA, Jonsen A, Truedsson L, Rantapaa-Dahlqvist S, Eriksson C, Alm G, Goring HH, Pastinen T, Syvanen AC, Rönnblom L: A risk haplotype of STAT4 for systemic lupus erythematosus is over-expressed, correlates with anti-dsDNA and shows additive effects with two risk alleles of IRF5. Hum Mol Genet 2008, $17: 2868-2876$

48. Cunninghame Graham DS, Akil M, Vyse TJ: Association of polymorphisms across the tyrosine kinase gene, TYK2 in UK SLE families. Rheumatology (Oxford) 2007, 46:927-930

49. Moser KL, Kelly JA, Lessard CJ, Harley JB: Recent insights into the genetic basis of systemic lupus erythematosus. Genes Immun 2009, 10:373-379.

50. Rönnblom LE, Alm GV, Öberg KE: Possible induction of systemic lupus erythematosus by interferon-a treatment in a patient with a malignant carcinoid tumour. J Intern Med 1990, 227:207-210.

51. Ioannou Y, Isenberg DA: Current evidence for the induction of autoimmune rheumatic manifestations by cytokine therapy. Arthritis Rheum 2000, 43:1431-1442.

52. Rönnblom LE, Alm GV, Öberg KE: Autoimmunity after a-interferon therapy for malignant carcinoid tumors. Ann Intern Med 1991, 115:178-183.

53. Strandberg L, Ambrosi A, Espinosa A, Ottosson L, Eloranta ML, Zhou W, Elfving A, Greenfield E, Kuchroo VK, Wahren-Herlenius M: Interferon-alpha induces up-regulation and nuclear translocation of the Ro52 autoantigen as detected by a panel of novel Ro52-specific monoclonal antibodies. J Clin Immunol 2008, 28:220-231.

54. Baccala R, Hoebe K, Kono DH, Beutler B, Theofilopoulos AN: TLR-dependent and TLR-independent pathways of type I interferon induction in systemic autoimmunity. Nat Med 2007, 13:543-551.

55. Miettinen M, Sareneva T, Julkunen I, Matikainen S: IFNs activate toll-like receptor gene expression in viral infections. Genes Immun 2001, 2:349-355.

56. Davis AM, Ramos HJ, Davis LS, Farrar JD: Cutting edge: a T-bet-independent role for IFN- $\alpha / \beta$ in regulating IL-2 secretion in human $\mathrm{CD}^{+}$central memory T cells. J Immuno/ 2008, 181:8204-8208.

57. Jego G, Palucka AK, Blanck JP, Chalouni C, Pascual V, Banchereau J: Plasmacytoid dendritic cells induce plasma cell differentiation through type I interferon and interleukin 6. Immunity 2003, 19:225-234.

58. Le Bon A, Thompson C, Kamphuis E, Durand V, Rossmann C, Kalinke U, Tough DF: Cutting edge: enhancement of antibody responses through direct stimulation of B and T cells by type I IFN. J Immuno/ 2006, 176:2074-2078

59. Uccellini MB, Busconi L, Green NM, Busto P, Christensen SR, Shlomchik MJ, Marshak-Rothstein A, Viglianti GA: Autoreactive B cells discriminate CpGrich and $\mathrm{CpG}$-poor DNA and this response is modulated by IFN- $a$. J Immunol 2008, 181:5875-5884.

60. Båve U, Vallin H, Alm GV, Rönnblom L: Activation of natural interferon-a producing cells by apoptotic $U 937$ cells combined with lupus Ig G and its regulation by cytokines. J Autoimmun 2001, 17:71-80.

61. Palucka AK, Blanck JP, Bennett L, Pascual V, Banchereau J: Cross-regulation of TNF and IFN-alpha in autoimmune diseases. Proc Natl Acad Sci U S A 2005, 102:3372-3377.

62. Eloranta ML, Lovgren T, Finke D, Mathsson L, Ronnelid J, Kastner B, Alm GV, Ronnblom $L$ : Regulation of the interferon-a production induced by RNAcontaining immune complexes in plasmacytoid dendritic cells. Arthritis Rheum 2009, 60:2418-2427.

63. Lee HM, Mima T, Sugino H, Aoki C, Adachi Y, Yoshio-Hoshino N, Matsubara K, Nishimoto N: Interactions among type I and type II interferon, tumor necrosis factor, and beta-estradiol in the regulation of immune responserelated gene expressions in systemic lupus erythematosus. Arthritis Res Ther 2009, 11:R1.

64. Shiozawa S, Kuroki Y, Kim M, Hirohata S, Ogino T: Interferon-a in lupus psychosis. Arthritis Rheum 1992, 35:417-422.

65. Raison CL, Demetrashvili M, Capuron L, Miller AH: Neuropsychiatric adverse effects of interferon-alpha: recognition and management. CNS Drugs 2005, 19:105-123.

66. Santer DM, Yoshio T, Minota S, Moller T, Elkon KB: Potent induction of IFN-a and chemokines by autoantibodies in the cerebrospinal fluid of patients with neuropsychiatric lupus. J Immunol 2009, 182:1 192-1201.

67. Fairhurst AM, Mathian A, Connolly JE, Wang A, Gray HF, George TA, Boudreaux CD, Zhou XJ, Li QZ, Koutouzov S, Banchereau J, Wakeland EK: Systemic IFN-a drives kidney nephritis in B6.Sle123 mice. Eur J Immuno/ 2008, 38:1948-1960.

68. Denny MF, Thacker S, Mehta H, Somers EC, Dodick T, Barrat FJ, McCune WJ, 
Kaplan MJ: Interferon-a promotes abnormal vasculogenesis in lupus: a potential pathway for premature atherosclerosis. Blood 2007, 110:2907-2915

69. Niessner A, Shin MS, Pryshchep O, Goronzy JJ, Chaikof EL, Weyand CM: Synergistic proinflammatory effects of the antiviral cytokine interferon-a and Toll-like receptor 4 ligands in the atherosclerotic plaque. Circulation 2007, 116:2043-2052.

70. Kirou KA, Lee C, George S, Louca K, Peterson MG, Crow MK: Activation of the interferon-a pathway identifies a subgroup of systemic lupus erythematosus patients with distinct serologic features and active disease. Arthritis Rheum 2005, 52:1491-1503.

71. Feng $X, W u H$, Grossman JM, Hanvivadhanakul P, FitzGerald JD, Park GS, Dong X, Chen W, Kim MH, Weng HH, Furst DE, Gorn A, McMahon M, Taylor M, Brahn E, Hahn BH, Tsao BP: Association of increased interferon-inducible gene expression with disease activity and lupus nephritis in patients with systemic lupus erythematosus. Arthritis Rheum 2006, 54:2951-2962.

72. Landolt-Marticorena C, Bonventi G, Lubovich A, Ferguson C, Unnitahn T, Su J, Gladman DD, Urowitz M, Fortin PR, Wither J: Lack of association between the interferon-alpha signature and longitudinal changes in disease activity in systemic lupus erythematosus. Ann Rheum Dis 2009, 68:1440-1446.

73. Petri M, Singh S, Tesfasyone H, Dedrick R, Fry K, Lal P, Williams G, Bauer J, Gregersen P, Behrens T, Baechler E: Longitudinal expression of type I interferon responsive genes in systemic lupus erythematosus. Lupus 2009, 18:980-989.

74. Baechler EC, Batliwalla FM, Ortmann WA, Espe KJ, Hughes KM, Wenberg NH, Kern M, Novitzke JM, Slattery CA, Koeuth T, Bauer JW, Tesfoyne H, Singh S, Petri M, Gregersen PK, Behrens TW: Gene signatures in peripheral blood predict future disease activity in patients with systemic lupus erythematosus. Arthritis Rheum 2005, 52:5700.

75. Petri M, Tesfasyone H, Singh S, Batliwalla F, Gregersen PK, Gillespie E, Ortmann WA, Espe KJ, Hughes KM, Wenberg NH, Slattery CA, Koeuth T, Behrens T: The systemic lupus erythematosus interferon signature is associated with current activity and is also predictive of hematologic and mucocutaneous disease activity at the next visit. Arthritis Rheum 2005, 52:S464

76. Biesen R, Demir C, Barkhudarova F, Grun JR, Steinbrich-Zollner M, Backhaus M, Haupl T, Rudwaleit M, Riemekasten G, Radbruch A, Hiepe F, Burmester GR, Grutzkau A: Sialic acid-binding Ig-like lectin 1 expression in inflammatory and resident monocytes is a potential biomarker for monitoring disease activity and success of therapy in systemic lupus erythematosus. Arthritis Rheum 2008, 58:1136-1145.

77. Bauer JW, Baechler EC, Petri M, Batliwalla FM, Crawford D, Ortmann WA, Espe KJ, Li W, Patel DD, Gregersen PK, Behrens TW: Elevated serum levels of interferon-regulated chemokines are biomarkers for active human systemic lupus erythematosus. PLoS Med 2006, 3:e491.
78. Fu Q, Chen X, Cui H, Guo Y, Chen J, Shen N, Bao C: Association of elevated transcript levels of interferon-inducible chemokines with disease activity and organ damage in systemic lupus erythematosus patients. Arthritis Res Ther 2008, 10:R112.

79. Svenungsson E, Gustafsson J, Leonard D, Sandling J, Gunnarsson I, Nordmark G, Jönsen A, Bengtsson AA, Sturfelt G, Rantapää-Dahlqvist S, Elvin K, Sundin U, Garnier S, Simard JF, Sigurdsson S, Padyukov L, Syvänen AC, Rönnblom L: A STAT4 risk allele is associated with ischemic cerebrovascular events and antiphospholipid antibodies in systemic lupus erythematosus. Ann Rheum Dis 2009, in press [Epub ahead of print].

80. Santiago-Raber ML, Baccala R, Haraldsson KM, Choubey D, Stewart TA, Kono DH, Theofilopoulos AN: Type-l interferon receptor deficiency reduces lupus-like disease in NZB mice. J Exp Med 2003, 197:777-788.

81. Braun D, Geraldes P, Demengeot J: Type I interferon controls the onset and severity of autoimmune manifestations in Ipr mice. J Autoimmun 2003, 20:15-25.

82. Wallac DJ, Petri M, Olsen N, Kirou K, Dennis G, Yao Y, Jallal B, Coyle A, Zeng L, Investigators L, White B: MEDI-545, an anti-interferon alpha monoclonal antibody, shows evidence of clinicla activity in systemic lupus erythematosus. Arthritis Rheum 2007, 56:S562-S563.

83. Yao Y, Richman L, Higgs BW, Morehouse CA, de los Reyes M, Brohawn P, Zhang J, White B, Coyle AJ, Kiener PA, Jallal B: Neutralization of interferon$\alpha / \beta$-inducible genes and downstream effect in a phase I trial of an antiinterferon-a monoclonal antibody in systemic lupus erythematosus. Arthritis Rheum 2009, 60:1785-1796.

84. Pestka S, Krause CD, Walter MR: Interferons, interferon-like cytokines, and their receptors. Immunol Rev 2004, 202:8-32.

85. Dzionek A, Sohma Y, Nagafune J, Cella M, Colonna M, Facchetti F, Gunther G, Johnston I, Lanzavecchia A, Nagasaka T, Okada T, Vermi W, Winkels G, Yamamoto T, Zysk M, Yamaguchi Y, Schmitz J: BDCA-2, a novel plasmacytoid dendritic cell-specific type II C-type lectin, mediates antigen capture and is a potent inhibitor of interferon a/ $\beta$ induction. J Exp Med 2001 194:1823-1834.

86. Barrat FJ, Coffman RL: Development of TLR inhibitors for the treatment of autoimmune diseases. Immunol Rev 2008, 223:271-283.

87. Rönnblom L, Pascual V: The innate immune system in SLE: type I interferons and dendritic cells. Lupus 2008, 17:394-399.

doi:10.1186/ar2884

Cite this article as: Rönnblom L: Potential role of IFNa in adult lupus. Arthritis Research \& Therapy 2010, 12(Suppl 1):S3. 